\title{
Mastery Learning in the Modern Context
}

\author{
Ishita Gupta
}

\begin{abstract}
This paper analyses whether mastery learning can be effectively introduced into the education system, with a specific focus on India. By presenting successful data studies on the experimental implementation of Mastery Learning, it discusses the significance of the findings and highlights the potential drawbacks of the widespread implementation of the learning philosophy and its feasibility into the real world.

Index Terms - Mastery Learning, Education.
\end{abstract}

\section{INTRODUCTION}

As the skills required to succeed in the modern world evolve rapidly, the demand for dynamic individuals who can self-drive progress grows in the job market. However, with the passing of time, it becomes increasingly apparent that the educational system has remained largely unchanged in the last 120 years and in some ways, fails to prepare students with thorough learning for success in the future. Critics argue that in an era of lifelong learning, our current education pedagogy fails to not only create graduates who fill this demand but also at the mission of education as a whole. Mastery learning is an educational philosophy initially proposed by Benjamin Bloom (1968), is an educational strategy that aims to tackle this, built on the idea of self-paced learning, learning not for test scores, but instead for mastery. In his theory of Mastery Learning, Bloom proposed the idea that given enough time and adequate conditions, children can attain mastery in any discipline of concern (Bloom 1968). With online learning platforms taking the centre stage in debates on the future of education, and websites like Sal Khan's Khan academy taking the reins in guiding the future of online mastery learning, the internet breathes new life into this ideology first introduced in the late 20th century. The question, however, still remains: can Mastery Learning be deployed and monitored at a large enough scale to create a measurable impact in global education?

\section{INTRODUCTION TO MASTERY LEARNING}

First formally introduced by Benjamin Bloom (Bloom 1968, 1976), Mastery Learning is an individually paced, personalised feedback based educational philosophy. According to Bloom, traditional models of education offer little student to student variation in instruction, inflexible timetables, and a disproportionate focus on test scores results. The theory of Mastery Learning argues that the seemingly arbitrary fixed time allotments to each student for learning the same volume of content do not account for differing student-to-student rates of information assimilation. Bloom argued that this creates incomplete learning, gaps in knowledge that may result in problems later as the subject material increases in complexity. According to Mastery learning, students can attain mastery in any given discipline when provided with sufficient time and personalised instructional techniques, varied to better match individual student learning requirements.

By breaking down material into smaller more discreet lessons with variable time allotments, students can follow a logical progression, learning at their own pace. In proceeding to the next lesson, they must be able to demonstrate mastery in the initial lesion(Anderson 2000). If the student's performance in the formative test indicates that they have not mastered the subject material, they undergo corrective instruction, where they are retaught, and then they are made to take the test again. This sequence of teaching, formative test, corrective instruction and the summative test continues until mastery has been attained(Block, Anderson 1976)

Sal Khan, founder of Khan Academy, explains why traditional learning strategies fail using a simple analogy of home-building. If concrete needed to form the walls of the house is not allowed sufficient time to dry and layers are added on the wet base, the structural integrity of the building sufferers(Khan 2015). Similarly, for a few students, the time allotted to learn certain subject material is appropriate, and they are able to grasp the content. For others, it is not and they end up rushing learning to make for tests, resulting in learning with many layers of gaps, gaps that are further carried on to their later education, which only build up as content gets more difficult.

In an extension of this analogy, we may consider the time it takes for paint to dry, which is different from the amount of time it takes for the concrete to dry. It would be inefficient to allocate the two the same drying amount of time to both. In the same way, the learning rates differ from person to person, and arbitrary standardised learning timelines can lead to inefficient learning.

The key differences between mastery learning and traditional learning models can be summarised in the table below. 
Table I: Differences between Mastery and Traditional Learning models

\begin{tabular}{|c|c|c|}
\hline & \begin{tabular}{|c|} 
Traditional Learning \\
Model
\end{tabular} & $\begin{array}{c}\text { Traditional Learning } \\
\text { Model }\end{array}$ \\
\hline $\begin{array}{l}\text { Time } \\
\text { Period }\end{array}$ & $\begin{array}{l}\text { Every student is taught } \\
\text { subject material in a } \\
\text { predefined time period, } \\
\text { after which they are } \\
\text { tested on their } \\
\text { knowledge and move } \\
\text { on to the next topic, } \\
\text { regardless of their } \\
\text { degree of understanding } \\
\text { of precursory content. }\end{array}$ & $\begin{array}{l}\text { Students can learn at their } \\
\text { own pace, repeating } \\
\text { difficult topics, and } \\
\text { speeding through easy } \\
\text { ones. They are tested } \\
\text { upon finishing a subtopic } \\
\text { and have to relearn until } \\
\text { mastery is attained }\end{array}$ \\
\hline Syllabus & $\begin{array}{l}\text { A fixed universal } \\
\text { syllabus limits the } \\
\text { content students learn } \\
\text { throughout the year }\end{array}$ & $\begin{array}{l}\text { Stronger students may } \\
\text { exceed the limits of the } \\
\text { fixed syllabus and earn } \\
\text { mastery in topics beyond } \\
\text { their peers in areas of } \\
\text { strength. }\end{array}$ \\
\hline Testing & $\begin{array}{l}\text { Tests are administered } \\
\text { periodically, and scores } \\
\text { are calculated and } \\
\text { transcribed, and gaps in } \\
\text { knowledge are } \\
\text { identified. Students are } \\
\text { then taught the next } \\
\text { topic regardless of } \\
\text { scores }\end{array}$ & $\begin{array}{l}\text { Students take tests at their } \\
\text { own pace and must attain } \\
\text { a level of mastery in tests, } \\
\text { before moving on to the } \\
\text { next topic. }\end{array}$ \\
\hline
\end{tabular}

\section{DATA STUdY 1: Co-OPERATIVE MASTERY LEARNING ON ACHIEVEMENT OF IX GRADERS}

Table II summarises the results from a study on the effect of teaching through a cooperative learning strategy on a sample of grade IX social studies students from two Government secondary schools of Ludhiana district of Punjab, India. The experimental group was exposed to the mastery learning program while the control received the conventional method of lecture and discussion. Performance in test in a standardised social studies test was used for data collection. (Kaur, Singh 2013)

The cooperative mastery learning strategy combines elements from both, mastery learning and cooperative learning (Slavin 1983). In summary, the strategy works by dividing students into groups where they learn from their peers. After this, they are individually provided with personalised formative teacher evaluations, and those who fail to achieve mastery are made to relearn from their peers.

Table II: Significance of difference in achievement (gain score) of the controlled and the experimental group

\begin{tabular}{|l|l|l|l|}
\hline Group & \multicolumn{1}{|c|}{ Mean } & $\begin{array}{l}\text { Standard } \\
\text { Deviation }\end{array}$ & T- ratio \\
\hline $\begin{array}{l}\text { Controlled } \\
\text { group }\end{array}$ & 12.82 & 6.43 & $5.82^{*}$ \\
\hline $\begin{array}{l}\text { Experimental } \\
\text { group }\end{array}$ & 34.39 & 3.50 & $5.82^{*}$ \\
\hline
\end{tabular}

*Significant at the 0.01 level of significance. Achievement is measured by mean gain in test scores. (Kaur, Singh 2013)

The data clearly show a higher mean test performance in the experimental group exposed to mastery learning. There is also a lower deviation in the level of learning, confirming Bloom's belief that mastery learning results in more uniform learning in the student groups. The authors of the study strongly recommend the cooperative mastery learning strategy on the basis of their findings. They also say that the cooperative-mastery strategy involves little extra equipment or technology and is simply peer to peer learning, it is a good way to potentially increase student performance.

\section{DATA STUdy 2: EFFECTIVENESS OF MASTERy LEARNING STRATEGY AND INQUIRY TRAINING MODEL ON PUPIL'S ACHIEVEMENT IN SCIENCE}

In a similar study to experiment 1 , this study aimed to investigate the effectiveness of Mastery Learning Strategy and Inquiry Training Model on the achievement of students in Science at VII Grade level. For the sake of pertinency, the findings from the Inquiry training model will be omitted, to focus only on the Mastery learning aspect of the study. The students of the control group and the mastery group were equated on intelligence using Cattell's Culture Fair Intelligence Test and then the control group was taught through the traditional learning method, while the experimental group underwent specifically designed mastery lesson plans. (Kalia 2005)

Table III: Results from investigation on the effectiveness of the Mastery Learning strategy on science achievement

\begin{tabular}{|l|l|l|l|}
\hline Group & Number & \multicolumn{1}{|c|}{ Mean } & $\begin{array}{l}\text { Standard } \\
\text { Deviation }\end{array}$ \\
\hline $\begin{array}{l}\text { Controlled } \\
\text { group }\end{array}$ & 30 & 62.80 & 11.85 \\
\hline $\begin{array}{l}\text { Experimental } \\
\text { group }\end{array}$ & 30 & 79.03 & 8.11 \\
\hline
\end{tabular}

(Kalia 2005)

A science test was used to measure the initial and final achievement of students. The mastery students took three mastery tests for the six units learnt over the course of the experiment. The findings again reveal that students exposed to mastery learning outperformed those exposed to traditional learning techniques, with higher mean achievement and lower standard deviation, showing a high degree of consistent learning through the experimental group.

\section{Data Study 3: Bombay Scottish School Mumbai}

Table IV summarises the data of student performance in test scores of middle school students in Bombay Scottish school after testing a Mastery Assessment operation carried out by Open Door Education. The students were taught the program through the traditional learning method, and performance was measured using a test. Then, the content was retaught using the mastery model, and learning was calculated again. 
Table IV: Effectiveness of Mastery Learning at Bombay Scottish School

\begin{tabular}{|l|l|l|l|l|}
\hline Subject & Grade & $\begin{array}{c}\text { Learning } \\
(\boldsymbol{\%})\end{array}$ & $\begin{array}{c}\text { RElearnin } \\
\mathbf{g}(\boldsymbol{\%})\end{array}$ & $\begin{array}{c}\text { Improvem } \\
\text { ent }(\boldsymbol{\%})\end{array}$ \\
\hline Biology & 7 & 57.56 & 70.69 & +13.13 \\
\hline Biology & 7 & 54.76 & 66.13 & +11.37 \\
\hline $\begin{array}{l}\text { Mathemat } \\
\text { ics }\end{array}$ & 7 & 54.88 & 65.14 & +10.26 \\
\hline
\end{tabular}

(Bombay Scottish school, Open Door Education 2018)

The results show that through reteaching through the mastery-based approach, it is clear that there has been a notable degree of improvement of student learning. However, it is unclear whether this learning arose as a product of mastery learning in specific, or simply because all students were forced to revise the same content they had already learned. Either way, it provides compelling evidence for the fact that for any given topic, when learning is incomplete, by spending more time on that topic, student performance can improve.

\section{V.FORESEEABLE ROADBLOCKS IN LARGE SCALE IMPLEMENTATION}

Mastery learning has largely proven to be successful in experimental conditions, but the question of whether it is suited for large scale national implementation is yet to be answered. A few foreseeable roadblocks are highlighted below.

1.Difficulty in measuring mastery in subjective subject areas: In some disciplines, specifically those concerned with the humanities, such as English and the social sciences, it is difficult to measure the degree of achievement (and mastery) due to the subjective nature of the content. The question of how to quantify when mastery in these subjects is attained will be a challenging task. While some subjects, like mathematics, have a clear right and wrong answer, allowing for easy allocation of test scores, when the line between correct and incorrect answers becomes blurred, so is the definition of mastery.

2.The Definition of Mastery: The second problem arises in our definition of the concept of mastery. What percentage of accuracy reflects mastery in a subject area? There is much debate over whether mastery aims to eliminate all imperfections in a child's cognitive development or if, for the sake of efficiency, it should allow a natural inevitable degree of imperfection that to slide (and what that reasonable degree of imperfection is). There is also the question of monotony, and the point where repeating content material becomes futile, being detrimental to the child's motivation and cognitive development.

3.Maximum and Minimum levels of learning: One defining aspect of mastery learning is the fact that it is inherently personalised, and students learn at a pace they are comfortable with. However, with this, the elusive question arises, what, if any, is the minimum and maximum amount of learning at any level or age category? The question of whether students should be simply required to achieve mastery in as many areas as possible, or should there be a minimum amount of mastery credits required in a given time period (an idea which is at odds with the basic principle of mastery). In the case of the implementation of the idea that 'students should simply do as much as they are comfortable with' how would we ensure that students are in fact pushing themselves to their maximum capacity? And in the case of overachievers, will there be an upper or closed limit or can students be expected to go on as far as they want to, and if yes what happens if they go beyond the curriculum that has been planned? These questions are challenging but also are mostly reflective of extreme scenarios, and should not be enough to derail a potential implementation of mastery learning towards the majority.

4.Mastery learning and its focus on test scores: A potential concern that could arise is mastery earnings focus on test scores and the question of how to incorporate practical, interpersonal, experimental and leadership experiences into mastery learning.Furthermore, there is the question of exactly what percentage of accuracy will be representative of mastery: a debate between a fixed score in every assessment, or one that is curved, varying on the basis of difficulty.

5.The implications of flexible learning timelines: The variable timelines that form the basis of mastery learning could also result in significant age differences in classrooms, and although Bloom theories that with practice, learning rates of slower and faster learners will be equalised, diminishing the gap between individual learning differences, this is yet to be experimentally proven.

6.Resources, training and investment and Shifts in Philosophy: Research suggests that a $95 \%$ mastery rate can be achieved with as little as a $10-20 \%$ increase in instructional effort. (Stamatis 1997). That being said, if current educational systems are already operating at full capacity, and many schools are already short for budget, a $20 \%$ increase could be overwhelming. The cost of retraining the teaching workforce to understand the mastery philosophy would also have to include the cost of changing mindsets, building dedication in teachers and belief in the mastery learning concept: the faith in all teachers that all learners are truly capable of achieving mastery.

7.Adaptation of students, parents and teachers and universities to this new educational philosophy: It is clear that the introduction of Mastery Learning would transform education as we know it. Its differences in philosophy and attitude would inevitably trigger reactions from parents, educators, admissions officers, employers and of course students. Would all stakeholders embrace this new learning approach, or is it possible that they will not fully understand it, having lived in a world with a dramatically different model of education? The mass restructuring of education would certainly have a ripple effect in the economy and through multiple stakeholders, effects that will certainly not be easy to predict. 


\section{CONCLUSION}

There is significant experimental evidence highlighting that the mastery learning philosophy can indeed be successful and that given enough time, every child can learn every topic to a high degree of accuracy. It is now a question of finding solutions to the more pervasive and unforeseen issues that can come with mastery learning's potential large scale real-world implementation. Governments can aid in finding these solutions by launching mastery learning classes on an experimental basis at a larger scale and recording progress every step of the way. With new technologies and increased internet access to the most remote parts of the globe, personalising education has never been easier. The role of randomised trials, for extended time periods in diverse subject groups, will be vital in collecting this and real-world data and achieving successful widespread applications of the learning philosophy.

\section{REFERENCES}

[1] "Benjamin S. Bloom (1968)" Learning for Mastery. Retrieved from https://files.eric.ed.gov/fulltext/ED053419.pdf

[2] "Benjamin S. Bloom (1976)". Human characteristics and school learning. New York: McGraw-Hill.

[3] "Khan, S. (2019)". Let's teach mastery- not test scores. Retrieved from https://www.ted.com/talks/sal_khan_let_s_teach_for_mastery_not_tes t_scores?language $=$ en.

[4] "Anderson, J. R. (2000)". Learning and memory: An integrated approach (2nd ed.). New York: John Wiley and Sons, Inc.

[5] "Block, J.H., \& Anderson, L.W” (1975). Mastery learning in classroom instruction. New York: Macmillan.

[6] "Kaur Jasvir, Singh Gurmit (2013)" Effect of Co-Operative Mastery Learning Strategy on Achievement in Social Studies of IX Graders. International Journal of Science and Research (IJSR)

[7] “Robert Slavin (1983)". Cooperative learning. New York: Longman.

[8] "Apoorva (2018)" How is Bombay Scottish School implementing mastery learning successfully? Open Door Education India

[9] “Ashok K. Kalia, (2005)" Effectiveness of Mastery Learning Strategy and Inquiry Training Model on Pupil's Achievement in Science. Indian Educational Review

[10] "D.H Stamatis (1997)" Chapter 17: Training and Learning Organisation TQM Engineering Handbook Marcel Dekker Inc 